\title{
Consensus planning in transport: The case of Vancouver's transportation plebiscite
}

\section{Abstract}

In 2015, a plebiscite was held on a new source of funding to support the expansion of the transit network in the Lower Mainland of Vancouver. Thus, in a region that has achieved admirable results over several decades through a strategic planning system based on a consensus model, civic leaders were forced to step outside this model to argue the case for a 0.5 percent increase to a local goods and service tax. This pitted a 'no new tax' grouping against a Better Transit and Transportation Coalition which brought supporters from across the community including from business, the unions, the environmental sector and students in support of the 'yes' case and the package of works crafted by consensus among municipal leaders. In this paper, we draw on in-depth key informant interviews with transportation and land use planners, municipal politicians and individuals involved in the 'yes' and 'no' campaigns built around the 2015 transport plebiscite. We show how the plebiscite was framed and how a critical component of Vancouver's planning ethos - consensus decision-making catalysed the formation of the coalition of 'yes' campaign supporters. Despite its defeat, this coalition remained persistent and unified in their support for the development of a new funding stream and for the continued expansion of transit infrastructure across the Lower Mainland. The paper draws lessons from the transit plebiscite and how its outcome highlight the unique role that consensus planning can play in achieving progressive outcomes to politically vexing questions in transport planning in Vancouver and elsewhere.

Key Words: Vancouver; plebiscite; transport policy; politics; transport governance 


\section{Introduction}

The consensus model of metropolitan governance and strategic land-use and transport planning in the city and region of Vancouver, Canada has been the focus of some interest for urban scholars for many years (Stone, 2014; Holden \& Scerri, 2013; Legacy, 2010; Punter, 2010; Grant, 2009, Mees, 2007). Since the 1970s, metropolitan agencies, largely the Greater Vancouver Regional District (now Metro Vancouver) and the related transport authority TransLink, have utilised a form of deliberative and consensus-based decision-making in the development and implementation of regional and local land-use and transport plans (Legacy 2010; 2012). These plans have contributed to relatively successful containment of urban development structured around the preservation of an agricultural reserve (Tomalty, 2002) and have guided the construction of extensions to the regional transit system.

Commitments by local and regional governments to prioritise transit provision have been maintained through this consensus model since the first Livable Region Plan (GVRD, 1976) was tabled, and then continued with the development of the Livable Region Strategic Plan (GVRD, 1996) and the Regional Growth Strategy (Metro Vancouver, 2011). Strategies of growth concentration and restrictions on increases in suburban road capacity have had considerable practical and political success since the 1970s (Stone and Kirk, 2017) helping to frame the transport governance arena for nearly four decades and helping to position Vancouver as an example of progressive transport planning in cities in western liberal democracies.

It is necessary to unpack what is it about Vancouver that makes it comparatively progressive. To this end we draw on Henderson's (2013, p. 19) conception of 'progressive mobility' to help explore the significance of the Vancouver region's dominant land use and transport paradigm since the 1970s, and the ongoing contention with the consensus model of decision-making that has served planning in the region. Vancouver's regional growth strategies have been underpinned by an ability to apply a consistent technical 'systems approach' to integrated land use and transport planning. This approach is framed by collectively expressed ambitions among elected local government officers to manage the negative impacts of automobility by focusing on the creation of complete communities, in which urban form is shaped by targeted transit investment (GVRD, 1993). Fundamental to this approach is a consensus model designed around the collective and coordinated participation of the municipal mayors in regional planning. This use of consensus is vital to our conception of Vancouver as a 'progressive mobility' culture: as Henderson notes, progressive mobility is shaped by democratic access to decisions (Henderson, 2013, p. 19). In the case of Metro Vancouver, democratic access is achieved through the participation of elected local government in the prioritisation of transport. 
More than many other similar city, Vancouver has maintained infrastructure commitments to support a progressive mobility agenda through a deliberative process involving municipal officials and communities. However, while outcomes in transit performance and travel times for the journey to work are impressive in comparison to similar urban regions, for example, in 2009 Vancouver had a public transport mode share of 16.5 per cent and annual boardings of 135 per capita compared with 7.0 percent and 40 boardings per capita in Auckland, NZ (Stone et al, 2010); and travel times for the journey to work fell marginally in Vancouver between 1992 and 2005 compared with an increase of over 15 percent in Toronto over the same period (Turcotte, 2005), conflict remains between supporters of transit-based suburban containment and advocates of car-oriented suburban expansion. In recent years, this has played out through increasing tensions between the Province and the region over mechanisms for revenue generation for transport infrastructure and services. This conflict has been exacerbated by rapid population growth that may see the region grow from a population of 2,460,000 (2016 Statistics Canada Census) to 3,440,000 by the year 2041 (Metro Vancouver, 2011, p. 68). Such rapid growth is already creating significant problems of housing affordability, and transit investment has failed to keep pace with increased demand for services. With this strain on resources, the need to expand transit services and to locate new revenue sources to support transit infrastructure investment is now high on the region's urban agenda (Kassam, 2016). However, the potential to address these shortfalls has been short circuited by decline in per capita revenue from property taxes (a key revenue stream for transit supply), due to continuing inflation above the 3\% annual tax indexation (Mayors' Council, 2015, p. 34), and declining fuel tax revenue, due to the increasing efficiency of the vehicle fleet.

In 2011, Christy Clark, became Premier of BC after the resignation of Gordon Campbell who had led the Liberal Party since 2001. She won her first election as Premier in 2013, defeating the New Democratic Party. During the campaign, Clark pledged to put future transit-funding increases to a plebiscite precipitating the formation of the Building Better Transport Coalition (BTTC). This coalition represented a diversity of environmental, labour and business interests who were drawn together in part by the strength of the commitment of Mayors to remain united, and a level of sophistication in understanding the role played by public transport in meeting the huge transport challenges facing the region.

Through our case study of lead up to and the conduct of this plebiscite over funding sources for transit expansion we examine the vulnerability of progressive mobility as defined by Henderson (2013). The case study allows us to set our assessment of the role of 'consensus' planning in Vancouver as a counter-narrative to the extensive literature that points to the co-option of 
consensus processes in urban planning by powerful corporate interests, including some specific local critiques (Holden, 2012). The paper draws on empirical work conducted in Vancouver by the authors in early 2016. This involved in-depth interviews with twenty-two planners, politicians, 'yes' and 'no' plebiscite campaigners, as well as representatives from the business, private sector unions and environmental community. In total twenty-two interviews were conducted. Three of the four leaders of the Better Transit and Transportation Coalition were interviewed (we were unable to interview the student representatives) as well as a representative from the 'No' campaign which was led by a single organisation. The remaining seventeen interviews were conducted with policy officials from TransLink, representatives on the TransLink Board, a selection of mayors from the Mayors' Council, and other transport advocacy bodies active in the Lower Mainland region. It was not possible to interview anyone from the Province (although considerable effort was made to secure interviews). These interviews were supported by a media analysis of the plebiscite and its reported impacts on transport governance since the vote. Additionally, a historical analysis was conducted of transportation plans produced by the region and the Province dating back to the early 1990s, as well as land use strategies dating back to the 1970s. The latter were produced by the metropolitan agency - the Greater Vancouver Regional District (GVRD). A critical discourse analysis was applied to identify key themes arising on the governance of transport planning, including institutional power, and procedural settings precipitating the decision to hold a plebiscite and the decision to form a non-partisan transport coalition.

The paper draws lessons from the transit plebiscite and how its outcome draws attention to the unique role that consensus planning can play in achieving progressive outcomes to politically vexing questions in transport planning in Vancouver and elsewhere.

\section{What counts as 'progressive' in transport planning?}

In this section we draw two disparate bodies of urban literature together to explore the relationship between progressive mobility outcomes and progressive forms of decision-making. We do this by casting a spotlight on the concept of progressive mobility developed by Henderson (2013) and consensus planning which has roots in Jurgen Habermas' communicative action and helped form the basis of early research into collaborative (Healey, 1997, Innes, 1995) and deliberative forms of planning (Forester, 1999). Taken together we build a framework upon which to examine the case of Vancouver in the second part of this paper. Our contribution is to also further unpack the notion of progressive mobility by examining the role consensus processes make to transport governance. 
Henderson (2013) describes progressive ideology in transport as one that challenges the automobile-centric mentality of both planning policy and investment decisions, as well as sociocultural connections to automobility. The latter has been the focus of mobility studies, led by Urry and Sheller (2006). Henderson situates this progressive ideology in a recognition of the "urgency inherent in this task" based on the environmental impacts of car-based mobility and that this task is to "contest the status quo" (p. 18) and to strive toward "ultimately car-free mobility" (p. 198). The status quo in this case is planning that reproduces automobility, or locks parts of the city into cardependency and unequal access to alternative forms of mobility extending spatial patterns of social disadvantage.

There are numerous examples of progressive mobility in cities globally. The bicycling culture in Copenhagen is an example. New York City after transforming once car-dominated city streets into pedestrian spaces is another inspiring example. However, progressive mobility is not solely about individual non-car mobility. It also concerns collective and public forms of mobility, and the practices and processes upon which planning for this occurs. In Europe, cities such as Zurich and Vienna provide further examples of progressive mobility structured around integrated rail and bus networks that effectively serve a range of urban forms at costs communities are willing to pay (Mees, 2010; Curtis and Scheurer, 2016). 'Progressive mobility' conjures up images of transport planning that privileges sustainable accessibility over logics of cumulative fractional travel time savings and the myth of 'congestion busting'. By placing ecological sustainability and spatial equity at its core, progressive transport planning serves larger societal imperatives.

In addition to commitments to land use and transport integration as examples of progressive transport, Henderson (2013) also describes progressive mobility as one that departs from selfinterested and individualised forms of mobility noting that, "To progressives, personal responsibility towards oneself includes social responsibility towards others" (p. 19). Henderson (2013, p. 19) goes further by equating progressive mobility to a,

systematic approach requir[ing] that government work for the public good...[and that] development cannot be left to the whims of capitalist speculation or be exclusively controlled by elites.....there must be democracy in planning...shaped by democratic access to decisions about the value of land and who gets to live there.

To do this, Henderson connects transport-planning ideals with those of democratic participation and transparent decision-making. However, it is not inevitable that a democratic process will simply deliver progressive mobility. Such an assumption fails to engage with the complexity of democratic 
decision fora to not only deliver progressive outcomes, but to protect those existing ideals, if they are ever realised.

\section{What role for consensus planning?}

Consensus-based decision-making holds the virtues of inclusivity and rational deliberation as its cornerstones (Forester, 1999). In part a response to the critiques of expert-led, techno-rationalist decision models that dominated planning in the $20^{\text {th }}$ century, consensus decision-making is ideally to be inclusive of different forms of knowledge including tacit and local knowledge of place (Legacy 2010; 2012), which would allow for the generation of new policies in deliberation with planners and elected officials. What this body of theory failed to account for was the embodied power disparities not only experienced by participants of consensus processes (Allmendinger and Haughton, 2012), but also the structural impediments that shaped what knowledge counted and what was worth knowing (Purcell, 2009). Neoliberalism in planning led to the marginalising of knowledge and values structured around social goals, in favour of market rationalisation and economic growth. Consensus has increasingly been observed in practice as an organising tool by governments and private sector decision-makers to achieve legitimacy for their respective ventures (Mäntysalo et al, 2015). Even when these discussions focus on understandings of wider aspirations for the city, there is little opportunity to resolve difference constructively. Disagreements are often sidelined, and contestations are dragged through lengthy and often very expensive and exhausting planning tribunal processes. In other cases, the disagreement becomes the focus of a political campaign and resistance (Darcy and Rogers, 2016; Legacy, 2016).

The critiques waged against consensus bear a powerful historical narrative showing how these decision processes seek to reproduce exclusion, marginality and oppression in the city. Research into settler-colonialism has produced a powerful example of structural forms of exclusion that continue to be propagated in planning (Porter and Berry, 2016). The closure of places where dissent and conflict can take shape to highlight different forms of inequality in the city has helped form the basis for critiques of consensus-based planning.

But what the critiques of consensus-based decision-making fail to engage with are the battles held and 'won' in previous years which may have produced a progressive outcome in the planning of cities at that time. Over time these decisions can be seen to have produced unintended spatial inequalities and exclusions, which demand further careful and considered debate. A common concern waged about public transport planning is that it can lead to increases in land values paving the way for gentrification and displacement of more vulnerable peoples. This can play out spatially 
as Danyluk and Ley (2007) describe. One recent example can be found in the City of Toronto. In writing about the election of a populist conservative mayor in the City of Toronto, Walks' (2015) spatial analysis showed support for this mayor coming from people who were "invested in protecting and masking the irrationalities of the auto-industrial complex" (p. 418). Walks argued that,

The more irrevocably each socio-spatial group is invested in distinct and opposing aspects of these political-economic formations and habitus, the more polarized will be their politics. This rise of the [Rob] Ford regime in Toronto is predicated on these spatial divisions, and the highly politicized disagreements over transportation policy that have resulted (Walks, 2015, p. 418-9).

Walks illuminates the problem cities like Toronto, and many other large cities in North America and Australia, experience from 'credit-driven gentrification' (Walks, 2015, p. 418), which includes producing inner city neighbourhoods where non-car-based options are more available. Pressures from housing unaffordability in the city and infrastructure investment in these areas are being exacerbated by creating a politics that can refract the progressive mobility agenda of land use and transport integration. The role consensus plays in serving to protect, as well as expand this agenda to these places that are under significant stress, demands that consensus-based decision-making be amenable to working with conflict. This is an area where considerable research in planning theory is now being directed (McAuliffe and Rogers, 2018).

One city-region where consensus planning has existed in parallel with progressive transport planning is the metropolitan region of Vancouver, Canada. Since the 1970s when Harry Lash, the Director of Planning for the Greater Vancouver Regional District from 1969 to 1975, published Planning in a Human Way (1976), consensus planning has formed a central tenet of regional decision-making. Lash's work, part memoir and part manifesto, argued for a tripartite model of consensus-based deliberation to help structure planning decision-making. This model was premised on inclusivity and open platforms for engagement and communication while highlighting the complementary roles played by professional planners, the public and local politicians in achieving a common planning vision for the future region of Vancouver. Lash's model helped to support democratic decisionmaking which served Vancouver's progressive mobility agenda through periods of sustained political contention in the 1990s and 2000s (Stone, 2008; 2014). The model offered a counter-proposition to what Lash saw then as an over-dependence upon technocratic, top-down knowledge formation when defining the urban challenges facing the region. At the time of his writing, these were concerns being expressed widely within the planning discipline (Arnstein, 1969; Davidoff, 1965). 


\section{The 2015 Vancouver Transportation Plebiscite}

The agency tasked with delivering and coordinating transportation in the Vancouver region is TransLink. The Canadian constitution gives provinces control over cities and regions and through provincial legislation powers can be passed on to cities. Given this, the British Columbia government provides the enabling powers to TransLink through the South Coast British Columbia Transportation Authority Act 1998. Established in 1999, the Greater Vancouver Transportation Authority (now known as TransLink) is tasked with providing a regional transportation system that moves people and goods and supports the regional growth strategy, provincial and regional environmental objectives (such as air quality and reduction of greenhouse gases), and the economic development of the transportation service region. Part 3 of this Act (section 32 and 33) states that in funding future rapid transport projects the BC Government must contribute funding for 60 percent of capital costs while the regional transport authority must contribute 40 percent. The regional contribution has typically been found from a variety of sources such as revenue from fares, a share of municipal property taxes and municipal gas tax. In some instances, the federal government may also contribute funding support.

Following Christy Clark's election in 2014, Bill 23 was introduced to the BC Parliament stating that "referenda respecting funding for the regional transportation systems be conducted". In 2015, the Vancouver region's Mayors' Council produced a plan for transit expansion outlining a series of funding possibilities that would generate new revenue streams for transport. Developed through consensus among the region's 23 municipalities, the plan was prepared in response to a request by the provincial Minister of Transportation and Infrastructure for the region to 'confirm its transportation vision and to clarify the costs, priorities and phasing for investments and action' (Mayors' Council, 2015, p. 1). This included the proposal to raise the regional sales tax by 0.5 percent. In what appears to have been a tactical move to evade responsibility for deciding a new revenue stream for transit, the province imposed a plebiscite on new revenue sources for transit, while at the same time committing funding to large-scale road-based projects in other parts of the region without requiring a plebiscite.

The sub-sections that follow present the outcomes of a thematic analysis arising from the policy, media and interview data collected in 2016. The generated themes describe the key factors leading up to decisions to pursue a plebiscite and the outcomes produced by that decision, including the implications for transit funding. This is followed by a discussion on transport planning governance, and what can be learned about the vulnerability of progressive mobility from the use of a one-off plebiscite in a politically vexing landscape of transport planning and funding. 


\section{Politicised transit funding in Vancouver}

Under established inter-governmental fiscal arrangements, funding for major infrastructure projects in Canadian cities and regions is co-funded across the three main tiers of government - local, provincial and federal - where each tier is responsible for supporting approximately one-third of capital investment. To support the provincial contribution, in British Columbia, the main source of revenue is property tax, as well as revenue from fees and charges such as user fees for sewer and garbage collection, including user fees from public transit (Province of British Columbia, 2012). The Motor Fuel and Carbon Taxes apply to the purchase of gasoline, diesel and natural gas fuels for automobiles and are provincially based schemes, whereby the Federal Gas Tax Fund is a transfer tax from the Federal government to Canadian municipalities to support local infrastructure projects. In recent years, revenue from fuel taxes has stagnated (Sinoski, 2015). Fuel consumption fell consistently to 2012, due to global improvements in vehicle efficiency and to Vancouver's successful integrated land-use and transportation planning that led to a fall in total vehicle kilometres travelled up until 2012 when growth in population and per capita vehicle ownership began to reverse this trend (Pacific Analytics, 2016; Stone \& Kirk, 2017).

In response to provincial pressure to identify new revenue sources, the passing of Bill 23 precipitated the plebiscite requiring the Mayors' Council to develop the Mayors' Council Transportation and Transit Plan (2015). This was a 10-year $\$ 8$ billion plan to extend multi-modal public transit services and transportation infrastructure across Metro Vancouver's municipalities and reflected an agreement made by the Mayors who voted 20 to 3 in favour of it. Implementation of the plan was expected to enable $70 \%$ of the region's residents to gain access to frequent transit via improved bus, light rail transit, sea bus/sea ferries, rail/SkyTrain services, as well as expanded networks of cycling and walking infrastructure and improvements to roads and bridges (Mayors' Council, 2015).

The Plan built on the Regional Growth Strategy (2011) land use plan and the Regional Transportation Strategy (2013) to support a broader 30-year transport vision for the region (Mayors' Council, 2015, p. 2). The investment package required funding through cost-sharing contributions from both the provincial and federal governments while the municipal contribution would be derived from a new revenue source - an increased goods and service tax - that could support Metro Vancouver's contribution to planned capital as well as ongoing operating and financing expenses (Mayors' Council, 2015, p. 2). But, the province would agree to this only if the tax increase was approved by a plebiscite. 
The next section explores the political background to the Provincial Liberal Government's 2013 election pledge to put an increase in public revenue for transit in the Lower Mainland to a vote; and examines how the consensus underlying the Mayors' transit plan provided the platform for business, unions, student groups and the environmental sector to coalesce behind a 'yes' campaign

\section{The 2015 transit plebiscite}

In 2013, as part of her re-election platform, British Columbia's Premier Christy Clark promised to put the future of public transit funding in the Lower Mainland (e.g. Metropolitan Vancouver) to a public vote (Today's BC Liberal, 2013, p. 18). This would be the first transport plebiscite ever held in British Columbia.

Despite the wishes of the region's mayors who warned that a rejection of new spending would result in the Lower Mainland struggling to keep pace with development and affordability pressures, on 18 December 2014, B.C. government officials formally announced that Elections BC would conduct a non-binding plebiscite. The legislative framework for the Plebiscite was completed on 12 February 2015 (Elections BC, 2015, p. 3) giving only three months before the mail-in plebiscite was due to end on May 29, 2015 for each camp to campaign and for a public discussion to take place. Unlike in some states in the US where referendum appear on ballots sometimes following a successful grassroots petitioning exercise, or a comparatively more mature strategy of coalition-building and campaigning is exercised (Henderson, 2013, Ch. 3), the experience of direct democracy is significantly less developed in Vancouver.

The voluntary plebiscite conducted by postal vote asked the citizens of the Lower Mainland if they would be prepared to accept an increase of $0.5 \%$ to a local goods and service tax to fund transit expansion; a tax that would apply to all non-essential items and to both residents and visitors to the Lower Mainland. Unlike many American cities where referenda on transportation funding are an established feature of urban democratic process (Schroeder \& Sjoquist, 1978), this was the first plebiscite ever held on a transportation issue in Vancouver and only the second in recent years to focus on a complex public policy issue. In total, only nine plebiscites have been held in BC since 1872 (Elections BC, 2017).

Campaign on the proposition took place between 16 March and 29 May 2015. The formal question was: "Do you support a one-half percentage point (0.5\%) increase to the Provincial Sales Tax in Metro Vancouver, dedicated to the Mayors' Transportation and Transit Plan, with independent audits and public reporting?". Eligible citizens included Canadian citizens, 18 years of age or older, who were a resident of $\mathrm{BC}$ for at least six months, resident of the transportation service region, and 
registered as a voter (Moving in a Livable Region, 2015). As shown in Figure 1, there were 1,551,507 registered voters at the initial mail-out and 757,183 valid ballots were returned (a turn-out of 48.6 per cent). There was a total of 290,151 (38.32 per cent) 'yes' votes to 467,032 'no' ballots (61.68 per cent) (Elections BC, 2015, p. 2). Only three districts voted in favour. Two of these, Belcarra and Bowen Island, have very small numbers of registered voters and one is located well outside the urban parts of metropolitan Vancouver. The other district in favour was the Metro Vancouver Electoral Area A which includes student accommodation in the University of British Columbia and the University Neighbourhoods. It is also small (only 2,708 votes were recorded, with a turn-out of 42.2 per cent). To help explain the favourable vote in this region it is worth noting that the Mayors' Council Plan included prioritising an extension of the Millennium SkyRail line westwards towards the University potentially relieving some of the stress on the existing corridor which is currently serviced by busses. It is also worth noting the student body representative group were one of the four main actors that participated in the early formation of the BTTC.

All other parts of the metropolitan region including the City of Vancouver and City of Surrey, which have the largest number of registered voters with 418,186 and 295,409 respectively, voted against the tax increase (Elections BC, 2015, p 22). The City of Vancouver was split almost exactly down the middle with just 50.8 per cent polling 'no' of the more than 210,000 votes cast, as noted earlier. The age of those who voted in the plebiscite also points to successful mobilisation of more conservative voters by the 'no' campaign. Only 37.6 per cent of eligible voters aged under 35 participated in the plebiscite, compared with 60.3 per cent participation among eligible voters aged 55 to 64 (Elections BC, 2015, p. 23). The decline in voting by young people is commensurate with a wider trend in Canada (Elections Canada, 2018). Also, such a lop-sided turnout with respect to age and city/suburban is not surprising. As Henderson (2013, p 32) posits "Spatial secession...is attached also to a broader conservative ambivalence towards cities, including an anti-urban image of the city as a place of vice and immorality". Debates around transit expansion and the dominance of the automobile is a spatial struggle, and contemporary debates as the one observed in Vancouver is also about how space is configured across metropolitan regions, and by whom (see Henderson, 2006).

Figure 1: Plebiscite results across the 23 regional municipalities. Orange column on the top is the number of people who voted 'no'; the blue column on the bottom is the number of people who voted 'yes' in the plebiscite.

[Insert figure 1] 
The role of the Province

From the start of the plebiscite campaign, supporters of the proposition mobilised through a 'Better Transit and Transportation Coalition'. They argued that economic productivity of the region would fall if investment to expand transit throughout the region did not happen. In an effort to appeal to multiple interest groups, the group drew the link between transit investment and regional productivity, by suggesting that:

The Metro Vancouver Congestion Improvement Tax will cost you less than 35 cents per day. This investment will have a lasting impact on the economy of the region, as goods and services move more easily, as we can grow sustainably, and as we stop wasting untold hours of time stuck in gridlock. The cost of doing nothing is billions in lost revenue and productivity. The cost of inaction is a price we can't afford (Better Transit and Transportation Coalition, 2015).

In the leadup to the plebiscite, the Province called the new levy the "Metro Vancouver Congestion Improvement Tax" and proposed that revenue generated from the tax would be subject to annual reviews, auditing and public reporting. In March 2015, the Province unveiled a plan to spend \$2.5 billion over three years to build roads, highways and bridges across the province but funding for these major transport proposals would not be considered as part of the plebiscite demonstrating a degree of inconsistency in what kinds of transport projects were subject to a plebiscite. A local newspaper reported the Mayor of the City of Vancouver as saying of the Province's transportation agenda:

Victoria's agenda is mystifying, on this front. Particularly when they have invested so much in roads and bridges in recent years. And somehow, transit, in particular, is being hauled through this process (Lupick, 2015).

In the same report, a similar concern was signalled about the contested expansion of the Massey Tunnel. This is a Provincial Government project that would open development to the marshy land outside the urban growth boundary in the Fraser Delta,

The province similarly did not require a vote before deciding it would replace the Massey Tunnel with an eight-lane bridge that will carry a price tag of $\$ 2$ billion or more. Likewise, the new 10-lane Port Mann Bridge saw taxpayers charged \$3.5 billion (plus tolls on crossings) without the province asking their permission (Lupick, 2015) 
The decision by the Provincial Government to hold a plebiscite can be seen as an attempt to evade responsibility for transit funding: another turn in the long contention over transport and development in metropolitan Vancouver outlined earlier. As several regional planners noted in interviews, it was feared that a 'no' vote in a swiftly orchestrated plebiscite would hinder and slow efforts to find new funding sources. And for some interviewees, the undermining of consensus and the region's planning efforts was perceived to be another motivation of the BC government, although no formal documentation could be obtained to support the assertion that was shared by a former regional GVRD planner,

the irony is that we have two authorities broadly speaking, TransLink and the Ministry, that are operating at cross purposes to each other. The ministry is building facilities that are to be paid for by tolls; it's a revenue source from this region; it's not like provincial income taxes. Residents of this region are being made to pay for these facilities like the Port Mann Bridge and the Massey Tunnel with no say on whether they are built and the toll. The transportation authority [TransLink] is being told that they have to have public approval in a plebiscite for any revenue generating sources for transit and transportation. It's bizarre. The provincial government with their tolling policy says that there has to be a free alternative, which is just insane in an urban context (Interviewee 8).

The setback the plebiscite produced could be interpreted as one of seeking to address the substantive problem of transit funding to support ongoing investment and expansion. It may be that leaving the decision solely to the Mayors does not protect transit funding from setbacks and episodes of dissensus. However, it does mean that a politically vexing and complex piece of public policy (as suggested by interviewee 8 ) was left to the whim of a swiftly orchestrated plebiscite where the question can be manipulated, re-interpreted and/or used as a vehicle to achieve other ends. In this case the plebiscite became a vehicle to expose a public agency to critiques which the plebiscite itself was not about, as described in the text below.

\section{Defending the consensus}

In the leadup to the plebiscite, and beyond the Mayors' agreement to support their own plan, a collection of community, industry and academic advocacy groups formed to create the Better Transit and Transportation Coalition (BTTC). Co-led through the combined leadership of the David Suzuki Foundation, the University of British Columbia student group, the Vancouver Board of Trade and the Labor Union, through the leadership of Unifor which is Canada's largest private sector union (UniFor, 2017), the BTTC became one of the largest nonpartisan coalitions to form in a Canadian city in recent 
times. The BTTC unified under one public policy issue: transportation funding. Comprising over 200 metropolitan Vancouver organisations (small, medium and large), the BTTC spanned the political spectrum - left and right - in support of a tax increase to expand funding for prioritised transport projects. The BTTC was not a political group and therefore not aligned with a political party, but the coalition acted politically by engaging directly in the wider public dialogue about the transport problems affecting the Lower Mainland and the social and environmental costs it associated with a 'no' victory.

In interviews conducted with members of this coalition about what motivated them to actively support the 'yes' campaign and to participate in the BTTC, one interviewee remarked upon why they could support a plan that was owned by all Mayors, through a consensus decision-making model.

[we could support this plan] primarily because the mayors had actually agreed to the plan. And not to be overly cheeky about it, but the fact they agreed to anything was a minor miracle. I have a long history with this group and the players change and they come and go, but this is a group that can't decide what to order for lunch and they actually got agreement on a 10-year vision with billions of dollars of infrastructure that actually had some coordination to it. And was it a perfect plan? Absolutely not. Lots of things you could improve and there were shortcomings. That didn't matter, we had agreement and that agreement has a value (Interviewee 9).

The collective commitment towards this plan was itself a remarkable achievement in urban democracy in so far as a collaborative and cooperative effort led to a consensus decision and a path forward. Indeed the plan contained transit projects for nearly most member municipalities, including expanding capacity of existing skyrail lines into the city, construction of light rail lines in Surrey and Langley, rapid transit towards the University of British Columbia campus, extension of the Millennium Line, more frequent all day bus services and 2,700 kilometres of new bikeways (Mayors' Council, 2015, p. iii \& 24-6). However, the plan also contained a commitment towards the delivery of these projects in a manner that resulted in priorities being set over what projects would be built first based on readiness and "If full funding does not become available, projects will be prioritized based on their performance towards achieving the goals and targets outlined in the Regional Transportation Strategy" (Mayors' Council. 2015, p. 23-6). But not to put too fine a point on the role of consensus, as this member of the Coalition said in response to the Mayors' shared ownership:

We were basically saying, and even in one of the speeches we delivered, when you see the head of a business association standing, linking arms with the head of the public 
sector unions, standing linking arms with the head of the David Suzuki Foundation, never mind the student bodies, these are entities which are very often on opposite sides of the conversations and very comfortably so. When you see all of us standing here linking arms, because it's the right thing to do for building our communities, then you know that you're onto something good. And that was a big part of our narrative (Interviewee 9).

The role of the Opposition

Despite the powerful and unified message coming from the Mayors around the 10-year plan, the no campaign had a somewhat more well-articulated and organised voice, led by the Canadian Taxpayers Federation, a federally incorporated, not-for profit group dedicated to lowering taxes, achieving less waste and more accountable government (CTF, 2016). The Canadian Taxpayers Federation were able to control the debate in the lead up to the plebiscite with their 'No Tax' campaign which positioned the 'yes' campaign in a defensive mode. They viewed this plebiscite as a unique opportunity to articulate their concerns about TransLink and their message was simple, yet effective: "TransLink is a too-wasteful and badly-run organization to be trusted with any more of your money" (Bateman \& Marshall, 2016: 36). This translated into a simple and attractive slogan: "No TransLink Tax". Jordan Bateman, the person behind the 'no' campaign, was a former councillor of the Township of Langley. He spoke of problems with TransLink operations and waste within the organisation (Bateman, 2015; Bateman \& Marshall, 2016). However, he and his organisation were also ideological supporters of small government. The latter suggests that the relationship between the 'Yes' and 'No' campaigners can be partly explained by the participant's ideological differences on the role of government in regional planning, a finding that echoes the work of Trapenberg Frick (2013).

The "No Translink Tax" was a message that resonated with people who were already overwhelmed by high costs of living and perceived the tax to be an additional burden (Skelton, 2015).

Furthermore, Bateman was also able to leverage the fact that the Mayors' Plan contained no new major transit lines running from the suburbs into downtown Vancouver. He labelled the BTTC as elitist and therefore not representing the views of the everyday taxpayer. Bateman also argued that it is was natural for many car commuters to feel like there was nothing in it for them. Following Danyluk and Ley (2007) describing the politics of suburban and anti-suburban ideology as this relates to gentrification and transport mode choice, the clash between the inner and outer suburbs was one that Bateman exploited throughout his campaign, by intervening and even shaping the debate with 
the question, so why vote in favour of a $0.5 \%$ regional sales tax (when the benefits of this tax will unlikely be felt by you) (Mason, 2015).

\section{After the vote}

Following the release of the results, TransLink officials were quick to criticize the plebiscite. They noted that the outcome was a vote against higher taxes and was not a vote against public transit, improved transportation networks or TransLink itself (Johnson \& Baluja, 2015). However, Vancouver's mayor Gregor Robertson remarked with respect to the results of the vote that "immediate governance changes to TransLink are critical".

In the weeks after the plebiscite, two TransLink senior officials were fired from the agency in a move meant to improve public perception of the agency. Whilst executive vice-president and BC Rapid Transit Company president and general manager were let go, governance issues remain unaddressed. The shuffling of executives was criticised as a poor solution to deeper institutional issues (Lee, 2015). The 'no' decision was also widely criticized by advocates of the plan, including most of the region's mayors, police and fire chiefs, and the BTTC coalition including business, unions, and environmental groups for being a knee-jerk reaction to a tax increase without consideration for the long-term benefits of improved transit services and regional transport connectivity.

A people's vote can be seen from afar as an enlightened exercise in democracy in its most direct form, however, the 'yes' campaign in Vancouver was marred by strategic errors and time constraints imposed by the province that would not allow for the crafting of effective and informative campaign material (Mason, 2015). In early 2015 the Mayors met with people experienced in administering plebiscites from California to gain expertise in how to formulate a successful 'yes' campaign. Key advice included:

make sure you have enough time, you're going to need at least two years. We didn't have two years. Make sure that you can check who's voted each week so you can track your voting. Another thing that he said, which later I think proved to be very important, was that you should have a public champion in addition to a coalition, and in my view that champion should have been the Premier, at least (Interviewee 2).

The advisors also cautioned the difficulty of charting a positive message that could deliver a successful 'yes' outcome. This was salient advice particularly in the context of such a short time given to campaigning and on a topic as complex as transport funding. Following the period of voting, follow up media commentary continued to connect the failure of the 'yes' campaign to a failed communications and marketing campaign outlining how one of the best performing integrated 
transport agencies in North America lost the confidence of the citizens it served, and how a consensus around integrated land use and transport planning could be unlocked.

Following the plebiscite, the Premier appointed the first provincial representative to sit on the TransLink Board of Directors. But from media analysis of the ongoing debate around the location of new funds to support transit, as of mid-2018, there has been no commitment on the part of the Provincial Government to heed the public call suggested by the 'no' vote win to change the governance of TransLink (Kieltyke, 2015). This is despite the fact that the call to reform TransLink was articulated boldly and upfront in the opening passages of the Mayors' Council Transport Plan, which read,

“The Mayors' Council is calling on the Provincial Government once again, to make additional amendments to the TransLink governance structure. The changes ... do not go far enough to instil public confidence in the operation of TransLink. It has always been, and continues to be, the Mayors' Council request that the Provincial Government amend the legislation to provide our Council with oversight of TransLink's operating budget. If that does not occur, we are not at all confident that our vision of an Investment Plan will be realized" (Mayors' Council, RSI, p. ii).

Three years have now past since the vote and the Mayors Council are still in the process of another consensus-based public consultation process focusing on how the projects in the plan will be funded. Since conducting the initial field work supporting this paper, British Columbia elected a new Premier who is a leader of the left of centre New Democratic Party, which was able to form government through coalition. The election revealed that the people of B.C. were unhappy with the use of a plebiscite to decide a new transit funding mechanism. Before the next Parliament could be decided through a coalition, and in an attempt to hang onto power, Christy Clark and her Minister responsible for TransLink heeded calls based on their significant loss of seats in the urban areas of Vancouver that "if Metro Vancouver mayors want a new transit funding mechanism like a regional sales tax, a referendum will no longer be required" (Britten, 2017). At the time of writing the Mayors' Council remain in discussion about how to continue funding their ambitious transport plan, and in the sequencing of priorities of major transport projects across the region.

\section{Conclusion}

The Vancouver transport plebiscite may exist as an aberration in the planning of future transport systems in this region, but it underscores the politically challenging issues of addressing transport funding in the context of a fragmented model of road and transit governance. As described in this 
paper, the consensus model embraced at the metropolitan level has provided the backbone to Vancouver's urban growth management strategy and its relative success in resisting car-based suburban expansion over nearly three decades. This model is unusual in the industrial western democracies, and it appears to have delivered positive results. For these reasons, non-Vancouverbased transport academics (like ourselves) continue to take a keen interest in the governance systems of Vancouver land-use and transport planning. But despite the advances in transport planning made in the metropolitan region of Vancouver under this consensus model, transportation policy remains a space of significant fragmentation, poor coordination, and modal privilege. This was observed in the questions the plebiscite raised over what transport decisions would be subject to a vote, and which would not. At the time of the transit plebiscite, controversial decisions were being made by the Province to invest significant money on the rebuilding and widening of bridges to service car-based mobility without also being subject to a plebiscite.

The decision to hold a plebiscite, taken by the governing party in $B C$ in opposition to civic leaders at a regional and municipal level, raises interesting questions about democracy and transport planning. Direct democracy, as a form of decision-making in transport planning, has had a long history in countries such as Switzerland and the United States. However, as a form of inclusive decisionmaking, direct democracy has been widely criticised in the deliberative democracy literature as being a crude assessment of public preferences and failing to consider the discursive and nuanced discourse that shape understandings and knowledge of complex problems (Dryzek, 2010). This has prompted research into deliberative polling and other such public choice methodologies that incorporate a deliberative period of dialogue and debate (Fishkin et al, 2005; LeDuc, 2015). The plebiscite in the case of Vancouver became an instrument to pervert the consensus-oriented model of decision-making as represented by the Mayors' Council. The plebiscite rendered visible a disconnection between the progressive mobility policies of compact and transit-oriented growth, which have shaped urban development along existing transit corridors, and the parts of the city where those policies have not fully benefitted. Campaigners for the 'yes' case had difficulty in communicating the 'transit success story' that Vancouver can tell on the international stage. The negative campaign waged by the Canadian Taxpayers Federation, which capitalised on the rhetoric that government institutions are too large, too wasteful and too incompetent to be responsible with greater amounts of taxpayer dollars, was akin to the more conservative mobility ideology described by Henderson (2013).

From our interviews, we can speculate on the factors that may have weakened the ability of the 'yes' side to prosecute its case. These include the institutionalisation of community engagement and 
consensus-building activities within the agencies of the GVRD and the municipalities, which meant that networks of 'grass-roots' activism needed to be re-created to fight the plebiscite campaign. In addition, the neo-conservative Harper Government (Prime Minister between 2006-2015) made a series of dramatic cuts to federal support to many of the organisations that formed the basis for the effective functioning of Canadian civil society (Whittington, 2013).

From the Vancouver case, it is interesting to observe the extent to which the 'yes' case was premised on a defense of a consensus achieved elsewhere. This signals the need for a far more nuanced engagement with the role that consensus plays in progressive transport planning. While Vancouver has maintained a strong commitment to build and expand its public transport service as evidenced by consistent investment, the stagnating revenue to support further investment rendered visible questions about who ought to bear the costs. We saw the formation of a community-wide coalition to argue in favor of a mild increase in the goods and service tax in the Lower Mainland. However, in part, the plebiscite was used to destabilize the existing consensus. In cities, like Vancouver where most public policy questions are addressed through delegate forms of democracy (in this case, by elected officials in a parliamentary system), direct democracy may appear as a radical gesture and one that can appear superficially to dislodge decision-making from the inevitability of party politics. Instead, the plebiscite represented a significant political moment that not only threatened to upend the consensus, but also revealed the vulnerability of this consensus and the need to continually defend progressive mobility.

For supporters of policies of progressive mobility in cities beyond Vancouver, this case study is something of a cautionary tale. It demonstrates the ease with which conservative ideology of the kind describe by Henderson (2013) that is anti-tax and anti-government can be mobilised as rhetoric against transit-oriented planning. In the challenging world of social media campaigning and slogans, any public agency, whatever its actual performance, is vulnerable to attacks (justified or not) of the kind levelled at Translink. While there were governance deficiencies associated with the structure of TransLink, which the Mayors' Council openly acknowledged in the opening pages of their regional transportation vision (Mayors' Council, 2015, ii), these deficiencies can be easily exploited, and they were in the context of an ill-conceived transit plebiscite in Vancouver. The structure of the plebiscite, including its short lead time, and a lack of history in transport voting in Vancouver, left little time for the 'yes' campaign to build capacity to constructively address the issues raised by the 'no' campaign and to help maintain the focus of the discourse on funding transit expansion.

Every jurisdiction has its own political culture that shapes how urban policy is developed and implemented. When assessing a plebiscite as a mechanism for policy change, understanding the 
local context in which it is being applied is critical to understanding the results. This includes the history of its politics as it manifests spatially across the geography of a region. Understanding this geography and its politics is paramount to gaining an in-depth appreciation for why votes win, and others fail, and the different politics - progressive, conservative and neoliberal - that are shaping these results. Although the plebiscite in Vancouver might have been designed as a tactical intervention by the Province into metropolitan transport planning, this does not mean that such mechanisms can never be used for progressive ends. Increasing or introducing a tax - be that a congestion charge, or an increase in property taxes, etc - can often create a politically vexing space to negotiate. But as the Coalition that formed in support of the 'yes' vote illuminated, a consensus model of decision-making at the local council scale can be powerful in attracting wide support across the constituent base. Whatever mechanisms of decision-making might be employed, the Vancouver case also shows that strategists for progressive mobility, whether they are in local councils, coalitions of elite organisations, or community advocacy groups, must constantly build their grassroots support with people that live in the myriad of different local geographies in cities and regions, and ground the debates into the local realities of transport access and mobility. 


\section{References}

Allmendinger, P., \& Haughton, G. (2012). Post-political spatial planning in England: a crisis of consensus?. Transactions of the Institute of British Geographers, 37(1), 89-103.

Arnstein, S. R. (1969) A ladder of citizen participation. Journal of the American Institute of planners, 35(4), 216-224.

Bateman, J. (2015) BC: Twelve months of Translink waste - No Translink Tax campaign unveils special 2015 calendar, Taxpayer.com Stand UP. Be Heard! Canadian Taxpayers Federation, accessed 12/04/2017: http://www.taxpayer.com/news-releases/bc--twelve-months-of-translink-waste---notranslink-tax-campaign-unveils-special-2015-calendar

Bateman, J., Marshall, H. (2016) Everyone... But the People: How everyday taxpayers overcame Vancouver's elite and defeated the Translink Tax, Canadian Taxpayers Federation, Regina.

Better Transit and Transportation Coalition. (2015) Your Yes vote will change everything, Vancouver, accessed 12/12/2016: http://www.bettertransit.info/get the facts archived

Britten, L. (2017) B.C. Liberals drop referendum requirements for new transit funding' CBC News, accessed 26/06/2018: https://www.cbc.ca/news/canada/british-columbia/transit-referendummetro-vancouver-liberals-1.4159550

Canadian Taxpayers Federation (2016) Who We are. Regina, accessed 12/12/2017:

http://www.taxpayer.com/about/

Curtis, C., \& Scheurer, J. (2016). Planning for public transport accessibility: an international sourcebook. Routledge.

Danyluk, M., \& Ley, D. (2007). Modalities of the new middle class: Ideology and behaviour in the journey to work from gentrified neighbourhoods in Canada. Urban Studies, 44(11), 2195-2210.

Darcy, M., \& Rogers, D. (2016). Place, political culture and post-Green Ban resistance: Public housing in Millers Point, Sydney. Cities, 57, 47-54.

Davidoff, P. (1965) Advocacy and pluralism in planning. Journal of the American Institute of planners, 31(4), 331-338.

Dryzek, J. (2010) Foundations and Frontiers of Deliberative Governance Oxford: Oxford University Press.

Elections B.C. (2015) Report of the Chief Electoral Officer on the 2015 Metro Vancouver Transportation and Transit Plebiscite, Victoria. 
Elections B.C. (2017) Plebiscites, Victoria, accessed 11/17/2017: http://elections.bc.ca/referendaplebiscites/plebiscites/

Elections Canada. (2018) Explaining the turnout decline in Canadian Federal Elections: A New Survey of Non-Voters, accessed 6/12/2018:

http://www.elections.ca/content.aspx?section=res\&dir=rec/part/tud\&document=correlates\&lang=e

Fishkin, J., \& Farrar, C. (2005). Deliberative polling: From experiment to community resource. The deliberative democracy handbook, 68-79.

Forester, J. (1999). The deliberative practitioner: Encouraging participatory planning processes. Mit Press.

Grant, J. L. (2009) Experiential planning: A practitioner's account of Vancouver's success. Journal of the American Planning Association, 75(3), 358-370.

GVRD. (1976) The Livable Region 1976/1986: Proposals to Manage the Growth of Greater Vancouver. Burnaby, Canada.

GVRD. (1996) Livable Region Strategic Plan. Burnaby, Canada: GVRD.

GVRD. (1993) Transport 2021: A Long-Range Transportation Plan for Greater Vancouver. Burnaby, Canada.

Healey, P. (1997). Collaborative planning: Shaping places in fragmented societies. UBC Press. Henderson, J. (2013) Street Fight: The politics of mobility in San Francisco, Boston: University of Massachusetts Press.

Henderson, J. (2006) Secessionist automobility: Racism, anti-urbanism, and the politics of automobility in Atlanta, Georgia. International Journal of Urban and Regional Research, 30(2), 293307.

Holden, M. (2012). Urban policy engagement with social sustainability in metro Vancouver. Urban Studies, 49(3), 527-542.

Holden, M. \& Scerri, A. (2013) More than this: Liveable Melbourne meets liveable Vancouver. Cities, $31,444-453$.

Innes, J. E. (1995). Planning theory's emerging paradigm: Communicative action and interactive practice. Journal of planning education and research, 14(3), 183-189.

Johnson, L., Baluja, T. (2015) Transit referendum: Voters say No to new Metro Vancouver Tax, transit improvements, CBC News, 2 July 2015, accessed 20/12/2017: 
http://www.cbc.ca/news/canada/british-columbia/transit-referendum-voters-say-no-to-new-metrovancouver-tax-transit-improvements-1.3134857

Kassam, A. (2016) Vancouver mayor on housing crisis: 'I never dreamed it would get this intense', The Guardian, 21 November 2016. Accessed 16/12/2017:

https://www.theguardian.com/world/2016/nov/21/vancouver-mayor-gregor-robertson-interview$\underline{\text { housing-crisis }}$

Kieltyka, M. (2015) British Columbians not satisfied with province's handling of TransLink: Poll, Toronto Metro, 24 November 2015, accessed 12/12/2017:

http://www.metronews.ca/news/vancouver/2015/11/23/people-not-satisfied-with-bcs-handling-oftranslink.html

Lash, H. (1976) Planning in a Human Way: Personal Reflections on the Regional Planning Experience in Greater Vancouver Vancouver, Canada: The Ministry of State for Urban Affairs.

LeDuc, L. (2015). Referendums and deliberative democracy. Electoral Studies, 38, 139-148.

Lee, J. (2015) TransLink makes changes at the top after failed referendum, Vancouver Sun, 17 July 2015, accessed 14/12/2017:

http://www.vancouversun.com/business/TransLink+makes+changes+after+failed+referendum+with +video/11213438/story.html? Isa=2eab-cf8a

Legacy, C. (2010) Investigating the knowledge interface between stakeholder engagement and planmaking. Environment and Planning A, 42, 2735-2752.

Legacy, C. (2012) Achieving legitimacy through deliberative plan-making processes - lessons for metropolitan strategic planning'. Planning Theory and Practice, 13, 71-87.

Legacy, C. (2016). Transforming transport planning in the postpolitical era. Urban studies, 53(14), 3108-3124.

Lupick, T. (2015) Mayor Gregor Robertson mystified by billions of dollars for bridges while public transport requires a vote, The Georgia Straight, 17 March 2015, accessed 22/12/2017:

https://www.straight.com/blogra/412291/mayor-gregor-robertson-mystified-billions-dollarsbridges-while-public-transit

Mäntysalo, R., Jarenko, K., Nilsson, K. L., \& Saglie, I. L. (2015). Legitimacy of informal strategic urban planning-observations from Finland, Sweden and Norway. European Planning Studies, 23(2), 349366. 
Mason, G. (2015) How not to conduct a transit plebiscite, The Globe and Mail, 20 March 2015, accessed 14/12/2017: https://www.theglobeandmail.com/globe-debate/how-not-to-conduct-atransit-plebiscite/article23545970/

Mayors' Council. (2015) Regional transportation investments: a vision for Metro Vancouver, Metro Vancouver, Vancouver.

McAuliffe, C., \& Rogers, D. (2018). Tracing resident antagonisms in urban development: agonistic pluralism and participatory planning. Geographical Research, 56(2), 219-229.

Mees, P. (2007) Can Australian cities learn from a 'Great Planning Success?'. State of Australian Cities. Adelaide, 1110-1116.

Mees, P. (2009). Transport for suburbia: beyond the automobile age. Routledge.

Metro Vancouver. (2011) Metro Vancouver 2040 Shaping our Future - Regional Growth Strategy, Vancouver.

Moving in a Livable Region. (2015) Metro Vancouver's Transit and Transportation Referendum, Vancouver: http://www.movinginalivableregion.ca/library/the-referendum/

Pacific Analytics (2015) The Impacts of the Carbon Tax on Motor Vehicle Fuel Usage in Metro Vancouver, Pacific Analytics, Victoria, BC.

Porter, L., \& Barry, J. (2016). Planning for Coexistence?: Recognizing Indigenous rights through landuse planning in Canada and Australia. Routledge.

Province of British Columbia. (2012) Municipal Revenue Sources Review: An analysis of revenue makeup, Ministry of Community, Sport and Cultural Development, Victoria.

Punter, J. (2010) The Vancouver achievement: Urban planning and design. UBC Press.

Purcell, M. (2009). Resisting neoliberalization: communicative planning or counter-hegemonic movements?. Planning theory, 8(2), 140-165.

Schroeder, L. D., \& Sjoquist, D. L. (1978) The rational voter: An analysis of two Atlanta referenda on rapid transit. Public Choice, 33(3), 27-44.

Sinoski, K. (2015) With the transit tax on stage, road pricing waits in the wings, Vancouver Sun, 4 April 2015, accessed 11/12/2017:

http://www.vancouversun.com/news/With+transit+stage+road+pricing+waits+wings/10942143/sto ry.html 
Skelton, C. (2015) How much would TransLInk's congestion tax cost you? Vancouver Sun, 14 February 2015, accessed 15/12/2017:

http://www.vancouversun.com/news/much+would+TransLink+congestion+cost/10812837/story.ht $\underline{\mathrm{ml}}$

Stone, J. (2008). Political factors in the rebuilding of mass transit: an investigation of failure in Melbourne since 1970 through comparisons with Perth and Vancouver. (PhD), Swinburne University of Technology, Melbourne.

Stone, J. (2014) Continuity and Change in Urban Transport Policy: Politics, Institutions and Actors in Melbourne and Vancouver since 1970. Planning Practice \& Research, 388-404.

Stone, J., Mees, P., \& Imran, M. (2010). Network planning for more effective public transport in New Zealand cities. Selected proceedings, 12th World Conference on Transport Research, Lisbon.

Stone, J., \& Kirk, Y. (2017). The "disruption" we really need: public transport for the urban millennium. In H. Dia (Ed.), Low Carbon Mobility for Future Cities: Principles and Applications. Stevenage, UK: Institution of Engineering and Technology.

Today's BC Liberals. (2013) Strong Economy, Secure Tomorrow - Debt Free BC, Victoria. Tomalty, R. (2002) Growth management in the Vancouver region. Local Environment, 7(4), 431-445. Trapenberg Frick, K. (2013). The actions of discontent: Tea Party and property rights activists pushing back against regional planning. Journal of the American Planning Association, 79(3), 190-200.

Turcotte, M. (2005). The Time it Takes to Get to Work and Back. Ottawa: Statistics Canada. Unifor. (2017) About Unifor, accessed 12/05/2017: http://www.unifor.org/en/about-unifor Sheller, M., \& Urry, J. (2006). The new mobilities paradigm. Environment and planning A, 38(2), 207226.

Walks, A. (2015) Stopping the 'war on the car': neoliberalism, fordism, and the politics of automobility in Toronto. Mobilities, 10(3), 402-422.

Whittington, L. (2013), Conservatives dismantling social programs built over generations, Toronto Star, 9 December 2013 accessed 12/11/2017:

www.thestar.com/news/canada/2013/12/09/conservatives dismantling social programs built ove $\underline{\text { r generations.html }}$ 